\title{
HUBUNGAN KONSUMSI CAIRAN DENGAN STATUS HIDRASI PADA PEKERJA INDUSTRI LAKI-LAKI
}

\author{
Khairunissa Andayani, Fillah Fithra Dieny*) \\ Program Studi Ilmu Gizi Fakultas Kedokteran Universitas Diponegoro \\ Jl.Dr.Sutomo No.18, Semarang, Telp (024) 8453708, Email : gizifk@undip.ac.id
}

\begin{abstract}
Background : Industrial workers were the kind of populations that most often perform intense physical labor in hot environment for a long time, which can induce dehydration due to water loss as a result of increased sweat and respiration. This condition causes increased fluid requirements on workers. Whereas some studies have shown that fluid intake on workers were inadequate compared with required fluid intake. The aim of this study was to analyzed the relationship between fluid intake with hydration status in male industrial workers.

Method : Observational research with cross sectional design was conducted in PT Komatsu Indonesia Jakarta with 73 workers as subjects selected by simple random sampling method. Data on characteristic of subject, nutritional status, temperature and humidity of the working environment, fluids intake, symptoms of dehydration, and hydration status. Fluid intake was measured by $3 \times 24$ hours recall and hydration status was determined by specific gravity urine measurement. Symptoms of dehydration were measured with questionnaire.

Result : This study found that 2,7 \% of workers consumed 6,0-7,9 liter water/day, 53,4\% of workers consumed 4,05,9 liter water/day, and 43,9\% of workers were consumed 2,0-3,9 liter water/day (the average of total fluid intake $4208,05 \pm 790,78 \mathrm{ml}$ and fluid intake requirement $6000-8000 \mathrm{ml}$ ). Only $28.8 \%$ of workers were considered well hydrated. Other subjects were classified as pre-dehydrated (mildly dehydrated 37,0\% and moderately dehydrated $15,1 \%)$, whereas workers considered dehydrated 19,2\%. Fluid intake related with hydration status $(r=-0,319$ and $p=0,006)$. Nutritional status not related with hydration status $(r=0,212$ dan $p=0,072)$.

Conclusion: There was relationship between fluid intake with hydration status in male industrial workers.

Keyword : fluid intake; hydration status; workers; male
\end{abstract}

\section{ABSTRAK}

Latar Belakang : Pekerja industri merupakan populasi yang paling sering melakukan kegiatan fisik di lingkungan panas dalam waktu yang lama sehingga berpotensi untuk mengalami dehidrasi karena kehilangan cairan akibat peningkatan pengeluaran air melalui keringat dan pernapasan. Hal tersebut menyebabkan kebutuhan cairan pada pekerja meningkat. Padahal beberapa penelitian menunjukkan bahwa konsumsi cairan pada pekerja masih kurang memenuhi kebutuhan. Tujuan penelitian ini untuk menganalisis hubungan konsumsi cairan dengan status hidrasi pada pekerja industri laki-laki.

Metode : Penelitian Observasional dengan desain cross sectional, bertempat di PT Komatsu Indonesia Jakarta dengan jumlah sampel 73 subjek yang dipilih dengan simple random sampling. Data yang dikumpulkan meliputi karakteristik subjek, status gizi, suhu dan kelembaban lingkungan kerja, konsumsi cairan, gejala dehidrasi, dan status hidrasi. Konsumsi cairan diukur dengan menggunakan recall selama 3x24 jam dan status hidrasi diketahui dengan pemeriksaan berat jenis urin. Gejala dehidrasi diukur dengan kuesioner.

Hasil : Pada penelitian ini ditemukan sebanyak 2,7\% pekerja mengonsumsi cairan 6,0-7,9 liter per hari, 53,4\% mengonsumsi cairan 4,0-5,9 liter per hari, dan 43,9\% mengonsumsi cairan 2,0-3,9 liter per hari (rerata total konsumsi cairan 4208,05 \pm 790,78 ml dan kebutuhan cairan 6000-8000 ml). Hanya 28,8\% pekerja yang memiliki status hidrasi baik. Sisanya ditemukan mengalami pre-dehidrasi (dehidrasi ringan 37,0\% dan dehidrasi sedang 15,1\%), sedangkan yang mengalami dehidrasi sebesar 19,2\%. Konsumsi cairan berhubungan dengan status hidrasi $(r=-0,319$ dan $p=0,006)$. Status gizi tidak berhubungan dengan status hidrasi $(r=0,212$ dan $p=0,072)$.

Simpulan : Terdapat hubungan konsumsi cairan dengan status hidrasi pada pekerja industri laki-laki.

Kata kunci : konsumsi cairan; status hidrasi; pekerja; laki-laki

\section{PENDAHULUAN}

Indonesia merupakan negara berpenduduk padat dengan tingkat hidup yang relatif rendah, dimana tenaga kerja tersedia dalam jumlah berlebih. Pengusaha pabrik atau perusahaan masih kurang memperhatikan kesehatan tenaga kerja, termasuk kesejahteraan dan kebutuhan gizi. ${ }^{1}$
Undang-undang Republik Indonesia No.13 tahun 2003 tentang ketenagakerjaan pasal 86 menyebutkan bahwa setiap pekerja/buruh mempunyai hak untuk memeroleh perlindungan atas keselamatan dan kesehatan kerja guna mewujudkan produktivitas kerja yang optimal. ${ }^{2}$ Tenaga kerja yang sehat dapat meningkatkan 
produktivitas dan keselamatan kerja, serta menurunkan ketidakhadiran karena sakit. ${ }^{3}$ Tenaga kerja dapat terjamin kesehatan dan produktivitas kerjanya secara optimal bila terdapat keseimbangan antara beban kerja, beban tambahan akibat lingkungan kerja, serta kapasitas kerja. ${ }^{4}$

Beban tambahan akibat lingkungan kerja meliputi faktor fisik, kimia, biologis, dan psikologis. Paparan lingkungan kerja fisik seperti lingkungan kerja panas yang terus berlanjut dapat mengakibatkan gangguan kesehatan, salah satunya adalah dehidrasi. ${ }^{5}$ Dehidrasi adalah kehilangan cairan tubuh yang berlebihan karena penggantian cairan yang tidak cukup akibat asupan yang tidak memenuhi kebutuhan tubuh dan terjadi peningkatan pengeluaran air. ${ }^{5-8}$ The Indonesian Hydration Regional Study (THIRST) menyatakan bahwa $42,5 \%$ orang dewasa mengalami kurang air tingkat ringan. ${ }^{9}$

Pekerja industri merupakan populasi yang sering melakukan kegiatan fisik di lingkungan panas dalam waktu yang lama sehingga paling berpotensi untuk mengalami kekurangan cairan karena pengeluaran keringat berlebih dan terjadi peningkatan respirasi, namun masalah ini masih sering diabaikan. ${ }^{3,8-12}$

Penelitian di Australia pada buruh tambang bawah tanah dengan suhu lingkungan kerja $36,2^{\circ} \mathrm{C}$ menunjukkan bahwa $60 \%$ pekerja memulai shift bekerja dalam keadaan dehidrasi. ${ }^{13}$ Penelitian lain di Australia pada pekerja outdoor menunjukkan bahwa $79 \%$ pekerja mengalami dehidrasi. ${ }^{14}$ Penelitian pada pekerja laundry di Semarang menunjukkan bahwa 50 dari 70 sampel atau $71,1 \%$ mengalami clinically dehydrated. ${ }^{15}$

Cairan yang hilang melalui keringat dan tidak diganti menyebabkan volume plasma menurun dan terjadi penurunan kemampuan fisik dan kognitif pekerja. ${ }^{9-10}$ Kehilangan cairan $5 \%$ atau lebih dapat menyebabkan gangguan kesehatan akibat tekanan panas (heat stress) yang disebut heat illness, yaitu heat cramps, heat exhaustion, dan heat stroke. ${ }^{5,6}$ Pekerja dalam lingkungan panas yaitu 3 jam dalam suhu $45^{\circ} \mathrm{C}$ dan dalam keadaan hipohidrasi, mengalami pengurangan kecepatan aliran darah dalam otak yang menimbulkan perasaan akan jatuh dalam posisi berdiri. ${ }^{16} \mathrm{Hal}$ tersebut dapat meningkatkan risiko cedera di tempat kerja.

Memastikan bahwa pekerja dalam lingkungan panas cukup terhidrasi dengan baik adalah salah satu cara yang paling efektif untuk melindungi kesehatan dan keselamatan kerja, serta meningkatkan produktivitas. ${ }^{11,17}$ Pemenuhan cairan melalui asupan sangatlah penting. Kebutuhan air pada pekerja dalam lingkungan panas adalah sebesar 6 liter, sedangkan pekerja yang sangat aktif butuh lebih dari 6 liter. ${ }^{10}$ Beberapa penelitian membuktikan bahwa konsumsi cairan pada pekerja masih kurang memenuhi kebutuhan. Penelitian pada pekerja hutan menunjukkan bahwa konsumsi cairan kurang dari yang seharusnya. ${ }^{18}$ Penelitian di semarang pada pekerja laundry dengan paparan panas suhu $30,1-33,3^{\circ} \mathrm{C}$ menunjukkan bahwa konsumsi cairan pekerja terbanyak selama 8 jam bekerja hanya 601-800 $\mathrm{ml}$, sedangkan rerata konsumsi air minum di rumah $1002,85 \mathrm{ml}^{15}$

Berdasarkan latar belakang di atas, maka perlu dilakukan penelitian mengenai konsumsi cairan dan status hidrasi pada pekerja dalam lingkungan panas. Penelitian ini akan dilakukan di PT Komatsu Indonesia yang merupakan pabrik pembuatan peralatan berat karena berdasarkan survei awal diketahui bahwa suhu lingkungan kerja panas.

\section{METODE}

Penelitian ini dilaksanakan pada pertengahan bulan Juni sampai awal Juli 2013 di PT Komatsu Indonesia yang merupakan salah satu pabrik pembuatan peralatan berat di Jakarta. Penelitian ini termasuk lingkup penelitian di bidang gizi masyarakat dan merupakan penelitian analitik observasional dengan desain cross sectional.

Populasi target dalam penelitian ini adalah seluruh pekerja industri, sedangkan populasi terjangkau adalah seluruh pekerja industri di foundry PT Komatsu Indonesia. Jumlah subjek dalam penelitian ini yaitu 73 subjek yang seluruhnya merupakan pekerja laki-laki dengan usia 20-47 tahun. Subjek diambil dengan cara simple random sampling. Kriteria inklusi yaitu tercatat sebagai pekerja industri peralatan berat PT. Komatsu Indonesia, berbadan sehat (suhu tubuh normal $=36^{\circ} \mathrm{C}-37^{\circ} \mathrm{C}$ ), tidak menderita penyakit ginjal dan diabetes mellitus, tidak sedang menjalani diet penyakit ginjal dan diabetes mellitus, serta tidak mengalami diare.

Data yang dikumpulkan dalam penelitian ini adalah karakteristik subjek, status gizi, suhu lingkungan dan kelembaban lingkungan kerja, konsumsi cairan, gejala dehidrasi, dan status hidrasi. Data karakteristik subjek diperoleh melalui wawancara langsung dengan menggunakan kuesioner meliputi nama dan tanggal lahir. Status gizi diperoleh melalui perhitungan indeks masa tubuh (IMT) dengan pengukuran langsung berat 
badan menggunakan timbangan digital dengan ketelitian $0,1 \mathrm{~kg}$ dan tinggi badan dengan menggunakan microtoise ketelitian $0,1 \mathrm{~cm}$. Kategori status gizi yaitu apabila IMT $<18.5 \mathrm{~kg} / \mathrm{m}^{2}$ maka subjek mengalami berat badan kurang, IMT $18.5-22.9 \mathrm{~kg} / \mathrm{m}^{2}$ memiliki status gizi normal, IMT 23.00-24.9 $\mathrm{kg} / \mathrm{m}^{2}$ mengalami berat badan lebih, dan $>24.9 \mathrm{~kg} / \mathrm{m}^{2}$ mengalami obesitas. Suhu dan kelembaban lingkungan kerja diperoleh dari pengukuran langsung pada pukul 10.00, 13.30, dan 15.30 WIB dengan menggunakan alat termometerhigrometer ruangan digital dengan ketelitian $0,1^{\circ} \mathrm{C}$.

Konsumsi cairan adalah cairan yang masuk dalam tubuh yang berasal dari minuman dan makanan. Total konsumsi cairan diperoleh dari konsumsi minuman baik air maupun minuman lainnya, serta cairan dari makanan yang diperoleh melalui dietary recall selama $3 \times 24$ jam pada 3 hari aktif kerja. Perhitungan jumlah total konsumsi cairan menggunakan rumus pertambahan total cairan dari minuman dan total cairan dari makanan yang dilihat dari DKBM 2005, kemudian dihitung rata-rata total konsumsi cairan selama $3 \times 24$ jam untuk mendapatkan rata-rata total konsumsi cairan sehari.

Status hidrasi adalah suatu kondisi yang menggambarkan jumlah cairan dalam tubuh seseorang yang dapat diketahui dengan cara pemeriksaan berat jenis urin (BJU). Metode berat jenis urin (BJU) dipilih karena mudah dilaksanakan, sering digunakan, waktu analisis singkat, ketepatan baik, biaya terjangkau, portabilitas alat baik, dan rendahnya risiko bagi subjek. BJU tidak tepat bila digunakan pada subjek yang menderita diabetes mellitus, demam, dan sindrom nefrotik karena dapat mempengaruhi nilai berat jenis, tetapi hal tersebut sudah dipertimbangkan melalui pemilihan subjek melalui kriteria inklusi.

Pengambilan sampel urin dilakukan setelah 6 jam bekerja dengan menggunakan botol kaca bening. Pemeriksaan BJU dilakukan di laboratorium dengan menggunakan urinometer ketelitian 0.002. BJU dikategorikan menjadi empat, yaitu status hidrasi baik apabila nilai BJU $<1.015$, pre-dehidrasi (dehidrasi ringan apabila nilai BJU 1.016-1.020 dan dehidrasi sedang apabila nilai BJU 1.021-1.025), dehidrasi apabila nilai BJU 1.026-1.030, dan dehidrasi secara klinis apabila nilai $\mathrm{BJU}>1.030$.

Pengolahan dan analisis data dilakukan dengan program komputer. Analisis univariat digunakan untuk mendeskripsikan masing-masing variabel. Untuk menganalisis hubungan konsumsi cairan dengan status hidrasi dan status gizi dengan status hidrasi pada pekerja industri yang sebelumnya diuji normalitas data dengan menggunakan uji Kolmogorof-Smirnov, digunakan uji rank Spearman.

\section{HASIL PENELITIAN \\ Gambaran Umum Tempat Penelitian}

PT Komatsu Indonesia merupakan salah satu pabrik pembuatan peralatan berat di Jakarta. Pengambilan sampel dilakukan di unit foundry plant karena suhu lingkungan kerja yang lebih panas dibandingkan dengan unit lain sehingga pekerja di bagian ini lebih berisiko mengalami dehidrasi. Foundry plant terdiri dari berbagai bagian yaitu melting, molding line, dan finishing. Melting merupakan proses peleburan baja dalam tungku dengan suhu mencapai $1600^{\circ} \mathrm{C}$. Molding line merupakan proses membuat cetakan dari pasir yang memiliki rongga didalamnya, nantinya akan diisi dengan material logam cair. Molding line terbagi dari beberapa bagian yaitu core molding line, molding line, dan big size molding. Finishing terdiri dari pre finishing dan finishing. Pre finishing merupakan proses merapikan produk yang baru dibongkar dari cetakan, sedangkan finishing merupakan proses perbaikan produk yang belum bagus.

Ruang gerak di foundry plant PT Komatsu Indonesia sangat luas, hal tersebut dapat dilihat dari perbandingan jumlah pekerja dengan luas tempat kerja yaitu 1:43 sampai 1:143, artinya setiap satu orang memiliki luas tempat kerja 43 sampai $143 \mathrm{~m}^{2}$ sehingga sirkulasi udara di tempat kerja baik. Sirkulasi udara yang baik juga terbentuk karena ruangan yang tidak tertutup rapat dan langit-langit pabrik yang tinggi yaitu 8-10 meter sehingga dapat mengurangi tekanan suhu udara yang panas.

Perusahaan menyediakan fasilitas seperti dispenser dan blower yang terdapat di semua bagian tempat kerja. Blower dapat mengurangi tekanan panas di lingkungan kerja yang berpengaruh terhadap status hidrasi. Jumlah dispenser dan blower disesuaikan dengan jumlah pekerja dan luas tempat kerja.

\section{Karakteristik Subjek Penelitian}

Jumlah subjek pada penelitian ini adalah 73 pekerja laki-laki. Karakteristik subjek penelitian dapat dilihat pada tabel 1. 
Tabel 1. Karakteristik subjek menurut usia, berat badan, tinggi badan, nilai IMT, dan berat jenis urin

\begin{tabular}{lccc}
\hline Karakteristik subjek & \multicolumn{3}{c}{$(\mathbf{n}=\mathbf{7 3})$} \\
\cline { 2 - 4 } & Minimum & Maksimum & Rerata \pm SD \\
\hline Usia (tahun) & 20 & 47 & $30,86 \pm 8,68$ \\
Berat badan $(\mathrm{kg})$ & 45,6 & 91,9 & $61,50 \pm 10,84$ \\
Tinggi badan $(\mathrm{cm})$ & 154,4 & 174,8 & $165,61 \pm 5,12$ \\
IMT $\left(\mathrm{kg} / \mathrm{m}^{2}\right)$ & 16,9 & 31,5 & $22,39 \pm 3,54$ \\
Berat Jenis Urin $(\mathrm{g} / \mathrm{ml})$ & 1.002 & 1.030 & $1.0176 \pm 0.00814$ \\
\hline Distribusi frekuensi subjek penelitian berdasarkan status gizi dapat dilihat pada tabel 2.
\end{tabular}

Tabel 2. Distribusi frekuensi subjek berdasarkan status gizi

\begin{tabular}{lcc}
\hline \multicolumn{1}{c}{ Karakteristik Subjek } & Frekuensi (n) & Persentase (\%) \\
\hline Status Gizi & 7 & \\
Berat badan kurang & 40 & 9,6 \\
Normal & 7 & 54,8 \\
Berat badan lebih & 19 & 9,6 \\
Obesitas & $\mathbf{7 3}$ & 26,0 \\
\hline Total & $\mathbf{1 0 0}$ \\
\hline
\end{tabular}

Subjek termuda berusia 20 tahun, sementara subjek tertua adalah 47 tahun. Proporsi pekerja yang berusia 20-30 tahun lebih besar $(58,9 \%)$ dibanding usia $31-40$ tahun $(19,2 \%)$ dan > 40 tahun $(21,9 \%)$. Subjek yang mengalami obesitas lebih besar $(26,0 \%)$ dibandingkan dengan subjek yang mengalami berat badan kurang $(9,6 \%)$ dan berat badan lebih $(9,6 \%)$.

Tujuh puluh dua pekerja $(98,6 \%)$ merupakan lulusan SMA sederajat, baik SMK, STM, maupun SMA itu sendiri. Hanya 1 orang pekerja $(1,4 \%)$ yang merupakan lulusan SMP. Hal ini disebabkan karena untuk bekerja di Foundry PT Komatsu Indonesia dibutuhkan minimal pendidikan SMA atau sederajat.

Suhu dan Kelembaban Lingkungan Kerja

Suhu berkaitan dengan status hidrasi seseorang. Pengukuran suhu dan kelembaban lingkungan kerja dilakukan di beberapa bagian yaitu melting, molding line, dan finishing. Hasil pengukuran suhu dan kelembaban lingkungan kerja pada pukul 10.00, 13.30, dan 15.30 WIB dapat dilihat pada tabel 3 .

Tabel 3. Suhu dan kelembaban lingkungan kerja

\begin{tabular}{|c|c|c|c|c|c|c|c|}
\hline \multirow[t]{2}{*}{ Bagian } & & \multicolumn{3}{|c|}{ Suhu $\left({ }^{\circ} \mathrm{C}\right)$} & \multicolumn{3}{|c|}{ Kelembaban (\%) } \\
\hline & Pukul & 10.00 & $\begin{array}{c}13.3 \\
0\end{array}$ & $\underset{0}{15.0}$ & $\begin{array}{c}10.0 \\
0\end{array}$ & $\begin{array}{c}13.3 \\
0\end{array}$ & $\begin{array}{c}15.0 \\
0\end{array}$ \\
\hline Core Molding Line & & 29,7 & 32,6 & 31.6 & 66 & 65 & 56 \\
\hline Molding Line & & 32,7 & 33,4 & 32,8 & 63 & 59 & 54 \\
\hline Big Size Molding & & 33,0 & 34,9 & 33,4 & 69 & 57 & 57 \\
\hline Melting & & 33,0 & 47,5 & 40,1 & 56 & 25 & 32 \\
\hline Pre Finishing & & 30,8 & 31,4 & 31,0 & 68 & 63 & 58 \\
\hline Finishing & & 31,2 & 32,6 & 31,8 & 67 & 64 & 60 \\
\hline Painting & & 29,3 & 30,2 & 29,6 & 69 & 67 & 62 \\
\hline Median & & 31,2 & 32,6 & 31,8 & 67 & 63 & 57 \\
\hline
\end{tabular}

Median suhu lingkungan kerja pada siang hari (13.30) lebih panas daripada pagi (10.00) dan sore hari (15.00). Hal tersebut disebabkan karena pengaruh suhu dari luar ruangan yang sedang mencapai puncaknya. Selain itu, pada siang hari juga terjadi puncak produksi sehingga menghasilkan panas pada lingkungan kerja. Suhu tertinggi terdapat pada bagian melting yang diukur pukul 13.30. Melting merupakan bagian terpanas karena terjadi proses peleburan logam dimana suhu didalam tungku mencapai $1600^{\circ} \mathrm{C}$. Proses peleburan dilakukan sebanyak 3 kali masingmasing selama 2 jam. Subjek melakukan aktivitas pekerjaan tersebut selama 30-60 menit setiap satu 
kali proses peleburan. Saat tidak melakukan aktivitas pekerjaan, subjek berada di ruangan dengan suhu yang lebih rendah untuk normalisasi suhu tubuh.

Median kelembaban tertinggi terjadi pada pagi hari dan semakin menurun pada siang dan sore hari. Kelembaban dipengaruhi oleh suhu udara. Jika suhu udara naik, maka kelembaban akan berkurang. Oleh karena itu, kelembaban tertinggi terjadi pada pagi hari dan terendah pada sore hari. Kelembaban terendah terdapat di bagian melting karena suhu lingkungan kerja yang lebih panas.

\section{Konsumsi Cairan Pekerja}

Nilai minimum, maksimum, rerata, dan standar deviasi konsumsi air, konsumsi minuman lainnya, dan cairan dari makanan dapat dilihat pada tabel 4 .

Tabel 4. Nilai minimum, maksimum, rerata, dan standar deviasi konsumsi air, konsumsi minuman lainnya dan cairan dari makanan

\begin{tabular}{|c|c|c|c|}
\hline \multirow[t]{2}{*}{ Karakteristik } & \multicolumn{3}{|c|}{$(n=73)$} \\
\hline & Minimum & Maksimum & Rerata \pm SD \\
\hline Konsumsi air (ml) & 1166,4 & 5023,50 & $2914,39 \pm 791,67$ \\
\hline $\begin{array}{l}\text { Konsumsi minuman lainnya } \\
(\mathrm{ml})\end{array}$ & $\begin{array}{c}80,90 \\
436,76\end{array}$ & $\begin{array}{l}1726,60 \\
1095,91\end{array}$ & $\begin{array}{c}559,03 \pm 31,85 \\
734,63 \pm 137,14\end{array}$ \\
\hline
\end{tabular}

Berdasarkan hasil pengukuran, rerata total konsumsi cairan adalah 4208,05 $\pm 790,78 \mathrm{ml}$, sedangkan total konsumsi cairan minimum 2445,78 $\mathrm{ml}$ dan total konsumsi maksimum mencapai $6407,79 \mathrm{ml}$. Total konsumsi cairan diperoleh dari konsumsi air, konsumsi minuman lainnya dan cairan dari makanan.

Konsumsi air lebih banyak dibanding konsumsi minuman lainnya maupun cairan dari makanan. Konsumsi air menyumbang sebesar 69,2 $\%$ dari total konsumsi cairan, sedangkan konsumsi minuman lainnya menyumbang sebesar $13,3 \%$ dan cairan dari makanan menyumbang sebesar $17,5 \%$. Konsumsi air tertinggi mencapai 5023,50 ml, sedangkan konsumsi minuman lain hanya mencapai 1762,60 $\mathrm{ml}$ dan cairan dari makanan $1095,91 \mathrm{ml}$

Total konsumsi cairan berasal dari konsumsi cairan di tempat kerja dan di rumah. Nilai minimum, maksimum, rerata, dan standar deviasi konsumsi cairan di tempat kerja dan di rumah dapat dilihat pada tabel 5 .

Tabel 5. Nilai minimum, maksimum, rerata dan standar deviasi konsumsi cairan di tempat kerja dan di rumah

\begin{tabular}{lccccc}
\hline \multicolumn{2}{c}{ Karakteristik } & & \multicolumn{3}{c}{$(\mathbf{n}=\mathbf{7 3})$} \\
\cline { 3 - 5 } \multicolumn{2}{l}{} & & Minimum & Maksimum & Rerata \pm SD \\
\hline Konsumsi & cairan di & tempat & 1370,32 & 4432,50 & $2605,98 \pm 685,42$ \\
kerja & & 912,70 & 2682,04 & $1602,07 \pm 366,38$ \\
Konsumsi cairan di rumah & & & \\
\hline
\end{tabular}

Konsumsi cairan di tempat kerja 1,65 kali lebih banyak dibandingkan dengan konsumsi cairan di rumah. Konsumsi cairan lebih banyak di tempat kerja karena lingkungan kerja yang panas dan tingkat aktivitas yang cukup tinggi sehingga pekerja lebih banyak membutuhkan cairan dan lebih cepat haus.
Total konsumsi cairan dikategorikan menjadi tiga kelompok berdasarkan jumlah konsumsi cairan yaitu 2,0-3,9 liter per hari, 4,05,9 liter per hari, dan 6,0-7,9 liter per hari. Distribusi frekuensi kategori konsumsi cairan dapat dilihat pada tabel 6 .

Tabel 6. Distribusi Frekuensi Konsumsi Cairan

\begin{tabular}{ccc}
\hline Kategori Konsumsi Cairan & Frekuensi (n) & Persentase (\%) \\
\hline $2,0-3,9$ liter per hari & 32 & 43,8 \\
$4,0-5,9$ liter per hari & 39 & 53,4 \\
$6,0-7,9$ liter per hari & 2 & 2,7 \\
\hline Total & $\mathbf{7 3}$ & $\mathbf{1 0 0 \%}$ \\
\hline
\end{tabular}


Hanya $2,7 \%$ subjek yang mengonsumsi cairan 6,0-7,9 liter per hari, sedangkan sisanya mengonsumsi kurang dari 6 liter per hari.

Gejala Dehidrasi
Pada penelitian ini didapatkan hasil berupa gejala dehidrasi yang dirasakan subjek selama satu minggu terakhir. Gejala dehidrasi dapat dilihat pada tabel 7.

Tabel 7. Gejala dehidrasi yang dirasakan subjek

\begin{tabular}{lcccccc}
\hline \multirow{2}{*}{ Gejala Dehidrasi } & \multicolumn{2}{c}{ Ya } & \multicolumn{2}{c}{ Tidak } & \multicolumn{2}{c}{ Total } \\
\cline { 2 - 7 } & n & \% & n & \% & n & \% \\
\hline Haus & 39 & 53.4 & 34 & 46.6 & 73 & $100 \%$ \\
Lemas & 35 & 47.9 & 38 & 52.1 & 73 & $100 \%$ \\
Kulit Kering & 10 & 13.7 & 63 & 86.3 & 73 & $100 \%$ \\
Bibir kering & 21 & 28.8 & 52 & 71.2 & 73 & $100 \%$ \\
Tubuh terasa panas & 30 & 41.1 & 43 & 58.9 & 73 & $100 \%$ \\
Jumlah urin relatif sedikit & 17 & 23.3 & 56 & 76.7 & 73 & $100 \%$ \\
\hline
\end{tabular}

Gejala dehidrasi yang paling banyak dirasakan subjek adalah haus $(53,4 \%)$, lemas $(47,9 \%)$, dan tubuh terasa panas $(41,1 \%)$. Gejala dehidrasi lainnya seperti kulit kering, bibir kering, dan jumlah urin sedikit jarang dirasakan subjek.

\section{Status Hidrasi Pekerja Industri}

Status hidrasi pada pekerja industri dapat dilihat pada tabel 8 .

Tabel 8. Status Hidrasi pekerja industri

\begin{tabular}{lcc}
\hline \multicolumn{1}{c}{ Karakteristik } & Frekuensi (n) & Persentase (\%) \\
\hline Status hidrasi & & \\
Hidrasi baik & 21 & 28.8 \\
Pre-Dehidrasi & & \\
$\quad$ Dehidrasi ringan & 27 & 37.0 \\
$\quad$ Dehidrasi Sedang & 11 & 15.0 \\
Dehidrasi & 14 & 19.2 \\
\hline Total & 73 & 100 \\
\hline
\end{tabular}

Pre-dehidrasi merupakan tahap awal terjadinya kekurangan cairan (dehidrasi) yang dikategorikan menjadi dehidrasi ringan dan dehidrasi sedang. Pada tahap dehidrasi ringan tubuh sudah mengalami kekurangan cairan sebesar $1-2 \%$, sedangkan pada tahap dehidrasi sedang tubuh sudah mengalami kekurangan cairan sebesar 3-4\%. Pada tahap dehidrasi, tubuh sudah mengalami kekurangan cairan 5-6\%.
Hasil pengukuran berat jenis urin menunjukkan bahwa hanya $28,8 \%$ subjek yang memiliki status hidrasi baik. Sisanya ditemukan subjek mengalami pre-dehidrasi (dehidrasi ringan $37,0 \%$ dan dehidrasi sedang $15,0 \%$ ), sedangkan yang mengalami dehidrasi sebesar $19,2 \%$.

Berikut ini merupakan gambaran status hidrasi subjek berdasarkan suhu lingkungan kerja di masing-masing bagian tempat kerja.

Tabel 9. Kategori Status Hidrasi Subjek berdasarkan Suhu Lingkungan Kerja

\begin{tabular}{clccccc}
\hline $\begin{array}{c}\text { Suhu }\left({ }^{\mathrm{O}} \mathrm{C}\right) \\
\text { Pukul }\end{array}$ & \multicolumn{1}{c}{ Bagian } & $\begin{array}{c}\text { Status } \\
\text { Hidrasi } \\
\text { Baik }\end{array}$ & $\begin{array}{c}\text { Dehidra } \\
\text { si } \\
\text { Ringan }\end{array}$ & $\begin{array}{c}\text { Dehidrasi } \\
\text { Sedang }\end{array}$ & Dehidrasi & $\begin{array}{c}\text { Tota } \\
\mathbf{l}\end{array}$ \\
\hline 32,6 & Core Molding & 4 & 5 & 0 & 4 & $\mathbf{1 3}$ \\
33,4 & Line & 4 & 6 & 3 & 2 & $\mathbf{1 5}$ \\
34,9 & Molding Line & 1 & 2 & 3 & 2 & $\mathbf{8}$ \\
47,5 & Big Size Molding & 2 & 4 & 1 & 2 & $\mathbf{9}$ \\
31,4 & Melting & 3 & 0 & 0 & 1 & $\mathbf{4}$ \\
32,6 & Pre Finishing & 6 & 9 & 4 & 3 & $\mathbf{2 2}$ \\
30,2 & Finishing & 1 & 1 & 0 & 0 & $\mathbf{2}$ \\
& Painting & & & & & \\
\hline & Total & $\mathbf{2 1}$ & $\mathbf{2 7}$ & $\mathbf{1 1}$ & $\mathbf{1 4}$ & $\mathbf{7 3}$ \\
\hline
\end{tabular}


Tabel 9 menunjukkan bahwa subjek yang mengalami dehidrasi ditemukan di semua bagian tempat kerja dengan proporsi terbanyak di bagian big size molding dan melting karena suhu mencapai $34,9^{\circ} \mathrm{C}$ dan $47,5^{\circ} \mathrm{C}$.

\section{Hubungan Konsumsi Cairan dengan Status Hidrasi}

Hasil penelitian menunjukkan bahwa konsumsi cairan berhubungan negatif dengan status hidrasi pada pekerja industri dengan nilai $\mathrm{r}=$ $-0,319$ dan $p=0,006$ yang artinya semakin tinggi konsumsi cairan, maka nilai berat jenis urin akan semakin rendah yang menunjukkan status hidrasi baik.

\section{Hubungan Status Gizi dengan Status Hidrasi}

Hasil penelitian menunjukkan bahwa status gizi tidak berhubungan dengan status hidrasi pada pekerja industri dengan nilai $\mathrm{r}=0,212$ dan $p=$ 0,072 .

\section{PEMBAHASAN}

Hasil penelitian menunjukkan bahwa terdapat hubungan negatif antara konsumsi cairan dengan status hidrasi pada pekerja industri. Hasil tersebut sesuai dengan teori dan hipotesis yang menyatakan bahwa terdapat hubungan konsumsi cairan dengan status hidrasi pada pekerja industri pabrik. Pekerja yang mengonsumsi cairan dalam jumlah cukup atau sesuai dengan kebutuhan tubuh maka akan memiliki status hidrasi baik, sedangkan pekerja yang asupan cairannya tidak memenuhi kebutuhan dapat mengalami dehidrasi. ${ }^{7}$ Dehidrasi adalah kehilangan cairan tubuh yang berlebih karena penggantian cairan yang tidak cukup akibat asupan cairan yang tidak memenuhi kebutuhan tubuh ataupun karena peningkatan pengeluaran cairan baik melalui urin, keringat, dan proses pernapasan. ${ }^{5-8}$

Hasil pengukuran berat jenis urin menunjukkan bahwa hanya $28,8 \%$ subjek yang memiliki status hidrasi baik. Sisanya ditemukan subjek mengalami pre-dehidrasi (dehidrasi ringan $37,0 \%$ dan dehidrasi sedang $15,0 \%$ ), sedangkan yang mengalami dehidrasi sebesar 19,2\% .

Pre-dehidrasi merupakan tahap awal sebelum benar-benar terjadinya kekurangan cairan (dehidrasi), yang dikategorikan menjadi dehidrasi ringan dan dehidrasi sedang. Pada tahap dehidrasi ringan tubuh sudah mengalami kekurangan cairan sebesar 1-2\% dan mengalami tanda-tanda dehidrasi seperti haus, lemah, lelah, sedikit gelisah, dan hilang selera makan. Pada tahap dehidrasi sedang tubuh sudah mengalami kekurangan cairan sebesar $3-4 \%$ dan mengalami tanda-tanda dehidrasi seperti kulit kering, mulut dan tenggorokan kering, volume urin kurang. Pada tahap dehidrasi, tubuh sudah mengalami kekurangan cairan 5-6\% dan mengalami tanda-tanda dehidrasi seperti sulit berkonsentrasi, sakit kepala, kegagalan pengaturan suhu tubuh, serta peningkatan frekuensi napas. Kehilangan cairan $>6 \%$ meningkatkan risiko gangguan kesehatan, seperti dapat mengakibatkan otot kaku dan colapse saat tubuh kehilangan cairan sebesar $7-10 \%$ dan dapat menurunkan volume darah serta berakibat kegagalan fungsi ginjal saat tubuh kehilangan cairan sebesar $11 \% .^{23}$

Penelitian di Australia pada buruh tambang bawah tanah dengan suhu lingkungan kerja $36,2^{\circ} \mathrm{C}$ menunjukkan bahwa $60 \%$ pekerja memulai shift bekerja dalam keadaan dehidrasi (BJU >1.022 $\mathrm{g} / \mathrm{ml}) .{ }^{13}$ Penelitian lain di Australia pada pekerja outdoor menunjukkan bahwa $79 \%$ pekerja mengalami dehidrasi (BJU > $1.021 \mathrm{~g} / \mathrm{ml}){ }^{14}$ Penelitian pada pekerja laundry dengan paparan panas suhu $30,1-33,3^{\circ} \mathrm{C}$ menunjukkan bahwa 50 dari 70 sampel atau $71,7 \%$ tersebut terbukti mengalami clinically dehydrated dengan $\mathrm{BJU} \geq$ $1.030 .^{15}$

Asupan cairan yang tidak memenuhi kebutuhan cairan tubuh dapat terjadi karena faktor kebiasaan minum pekerja. Berdasarkan hasil penelitian, sebanyak $90,4 \%$ subjek minum $>8$ kali sehari. Pada pekerja dalam lingkungan panas harus lebih memperhatikan frekuensi minum yang lebih sering. ${ }^{5}$ Menurut U.S. Army tentang pengaturan tekanan panas dan manajemen korban akibat tekanan panas, pekerja dalam tekanan panas dengan suhu diatas $30^{\circ} \mathrm{C}$ dan aktivitas kerja sedang perlu mengganti asupan cairan sebanyak $700 \mathrm{ml}$ per jam. ${ }^{10}$ Jika selama satu jam seorang pekerja minum 2 kali, maka selama tujuh jam bekerja seorang pekerja harus minum sebanyak 14 kali.

Selain itu, ditemukan sebanyak $72,6 \%$ pekerja memiliki kebiasaan minum saat sudah merasa haus. Padahal haus merupakan respon bahwa tubuh telah kehilangan cairan sebesar 1-2\% berat badan tubuh. ${ }^{6}$ Respon tersebut dikendalikan oleh sistem saraf pusat. Saat terlambat minum, air tubuh menurun, dan osmolalitas cairan tubuh meningkat. Ada perbedaan waktu antara tubuh mulai kekurangan air dengan muncul rasa haus. Haus muncul setelah beberapa menit organ tubuh utama kekurangan air dan memberi sinyal ke hipotalamus. Seharusnya seseorang mengonsumsi cairan sebelum merasa haus, tetapi hanya sebagian kecil pekerja yang minum sebelum merasa haus $(15,1 \%)$. 
Asupan cairan yang tidak memenuhi kebutuhan cairan tubuh juga dapat terjadi karena jumlah dispenser yang disediakan di masingmasing bagian hanya 1 sampai 2 buah, sedangkan pabrik memiliki tempat kerja yang luas. Hal tersebut mempengaruhi pekerja dalam menjangkau air minum karena letak dispenser yang jauh.

Menurut Institute of Medicine tentang rekomendasi asupan air, kebutuhan cairan pada pekerja dalam lingkungan panas $\left(30-35^{\circ} \mathrm{C}\right)$ dengan intensitas kegiatan fisik aktif sampai sangat aktif adalah sebesar 6-8 liter per hari. ${ }^{9,10}$ Meskipun konsumsi cairan termasuk tinggi untuk orang dalam kondisi normal dengan kebutuhan cairan 2 liter per hari, namun ternyata jumlah tersebut masih kurang dari pemenuhan kebutuhan cairan yang seharusnya dikonsumsi pekerja dalam lingkungan panas. Berdasarkan jumlah kebutuhan cairan tersebut, sebanyak 2,7\% subjek mengonsumsi cairan 6,0-7,9 liter per hari, 53,4\% mengonsumsi cairan 4,0-5,9 liter per hari, dan sisanya mengonsumsi cairan 2,0-3,9 liter per hari. Total konsumsi cairan pada pekerja masih kurang dari kebutuhan yang seharusnya (rerata total konsumsi cairan 4208,05 \pm 790,78 ml). Penelitian lain pada pekerja laundry dengan paparan panas suhu $30,1-33,3^{0} \mathrm{C}$ di semarang menunjukkan bahwa total konsumsi cairan pekerja yaitu $1603,85-1802,85 .^{15}$

Kebutuhan air seseorang selain dipengaruhi umur, jenis kelamin, suhu lingkungan, dan aktivitas fisik, juga dipengaruhi ukuran fisik atau status gizi. Pada penelitian ini status gizi bukan merupakan variabel perancu karena hasil penelitian menunjukkan bahwa status gizi tidak berhubungan dengan status hidrasi. Dehidrasi tidak hanya ditemukan pada subjek yang mengalami kelebihan berat badan saja tetapi juga ditemukan pada subjek dengan status gizi baik dan kekurangan berat badan. Status hidrasi lebih dipengaruhi oleh kecukupan konsumsi cairan yang sesuai dengan kebutuhan dan adanya faktor suhu lingkungan yang tinggi sehingga terjadi peningkatan pengeluaran cairan melalui pernapasan dan keringat yang menyebabkan kebutuhan cairan tubuh meningkat. ${ }^{3,8-12}$

Bila kecukupan konsumsi cairan terpenuhi sesuai kebutuhan dalam lingkungan panas maka status hidrasi akan baik, sebaliknya jika konsumsi cairan kurang karena suhu lingkungan yang tinggi maka walaupun seseorang mengalami kelebihan berat badan ataupun kekurangan berat badan, tetap berisiko untuk mengalami dehidrasi. Hasil penelitian menunjukkan bahwa subjek yang mengalami dehidrasi ditemukan di semua bagian dengan proporsi terbanyak di bagian big size molding dan melting karena suhu lingkungan di bagian tersebut lebih tinggi dibandingkan dengan bagian lain.

Dehidrasi yang dialami pekerja disebabkan karena peningkatan kebutuhan cairan akibat faktor suhu lingkungan dan tidak diimbangi dengan asupan cairan yang cukup. Suhu lingkungan kerja yang tinggi menyebabkan pengeluaran cairan tubuh melalui pernapasan dan keringat meningkat. ${ }^{3,8-12}$ Pengukuran suhu di lingkungan kerja foundry plant PT komatsu Indonesia menunjukkan bahwa median suhu udara berada diatas nilai ambang batas yang ditetapkan yaitu sebesar $31,2-32,6^{\circ} \mathrm{C}$. Menurut Standar Nasional Indonesia (SNI) 2004 dan keputusan menteri tenaga kerja nomor: kep-51/men/1999, nilai ambang batas (NAB) iklim kerja (panas) adalah $25-30^{\circ} \mathrm{C}{ }^{19,20}$

Pekerja dalam lingkungan panas dapat mengalami tekanan panas sehingga tubuh akan melakukan adaptasi dengan lingkungan. Saat suhu lingkungan meningkat, maka suhu tubuh akan meningkat, kelenjar hipotalamus akan mengaktifkan mekanisme regulasi panas tubuh dengan memberikan reaksi untuk memelihara panas yang konstan dengan menyeimbangkan panas yang diterima dari luar tubuh dengan kehilangan panas dari dalam tubuh melalui proses penguapan yaitu pernapasan dan keringat. ${ }^{4-6,21,22}$ Penguapan terbanyak terjadi melalui keringat. Keringat yang berlebih dapat menyebabkan dehidrasi bila tidak diikuti dengan asupan cairan yang cukup. ${ }^{5}$

Dehidrasi pada pekerja dapat menurunkan kemampuan kognitif seperti penurunan konsentrasi dan daya ingat sesaat, mempengaruhi suasana hati dan semangat kerja, serta menurunkan kapasitas kerja fisik akibat kelelahan, lemas, atau pusing. ${ }^{3,9,10,17}$ Hal tersebut dapat menurunkan produktivitas kerja, meningkatkan risiko kecelakaan kerja dan ketidakhadiran karena sakit. ${ }^{4}$ Produktivitas, keselamatan, dan kesehatan pekerja perlu dijaga agar dapat menjalankan pekerjaan semaksimal mungkin sehingga dapat mencapai keuntungan yang maksimal bagi perusahaan. Apabila paparan tekanan panas terus berlanjut, maka dapat menyebabkan gangguan panas seperti heat cramps atau kejang otot, heat exhaustion atau kelelahan $_{s}$ dan heat stroke. Heat stroke terjadi saat tubuh kehilangan cairan $15 \%$ dan suhu tubuh meningkat sehingga menyebabkan kerusakan jaringan. ${ }^{5-6,15,18}$ 
Berdasarkan hasil penelitian, ditemukan suhu tertinggi mencapai $47,5^{\circ} \mathrm{C}$ di bagian melting. Untuk mengurangi risiko terjadinya gangguan kesehatan akibat lingkungan kerja bersuhu tinggi, perlu disediakan tempat sejuk dengan suhu 24$26^{\circ} \mathrm{C}$ yang terpisah dengan tempat proses kerja untuk pemulihan, tetapi pekerja perlu masuk ke dalam tempat adaptasi terlebih dahulu sebelum masuk ke dalam tempat sejuk. PT Komatsu telah menyediakan tempat sejuk untuk pekerja di bagian melting, tetapi pekerja memiliki kebiasaan langsung masuk ke tempat sejuk tanpa ke tempat adaptasi terlebih dahulu.

\section{SIMPULAN}

Hanya $28,8 \%$ pekerja yang memiliki status hidrasi baik. Sisanya ditemukan subjek mengalami pre-dehidrasi (dehidrasi ringan $37,0 \%$ dan dehidrasi sedang 15,0\%), sedangkan yang mengalami dehidrasi sebesar 19,2\%. Hal tersebut dimungkinkan karena suhu lingkungan kerja yang tinggi $\left(>30^{\circ} \mathrm{C}\right)$ sehingga terjadi peningkatan kebutuhan cairan mencapai 6000-8000 ml, namun ternyata hanya $2,7 \%$ subjek yang mengonsumsi cairan $>6$ liter per hari. Konsumsi cairan berhubungan dengan status hidrasi pada pekerja, sedangkan status gizi tidak berhubungan dengan status hidrasi pekerja.

\section{SARAN}

Perlu peningkatan asupan cairan bagi pekerja sesuai kebutuhan cairan tubuh untuk mencegah terjadinya dehidrasi. Hal tersebut dapat dilakukan dengan meningkatkan fasilitas perusahaan untuk mempermudah pekerja dalam mengakses air minum, misalnya dengan menambahkan jumlah galon dan dispenser atau menyediakan botol minum yang mudah dibawa saat bekerja. Selain itu, juga diperlukan edukasi pada pekerja tentang kebutuhan cairan untuk pekerja dalam lingkungan panas dengan aktivitas tinggi, tanda-tanda dehidrasi, akibat dehidrasi, dan cara mencegahnya.

\section{UCAPAN TERIMA KASIH}

Penulis mengucapkan terima kasih kepada Tuhan Yang Maha Esa, orang tua, seluruh subjek penelitian, PT Komatsu Indonesia yang telah memberikan kesempatan untuk melakukan penelitian, teman-teman, serta berbagai pihak yang telah membantu dan memberi doa, dukungan serta motivasi dalam penyusunan karya tulis ilmiah ini. Penulis juga mengucapkan terima kasih kepada Fillah Fithra Dieny, S.Gz, M.Si selaku pembimbing dan para reviewer, Prof. dr. H. M. Sulchan, MSc., DA. Nutr., Sp.GK dan Nuryanto, S.Gz, M.Gizi atas kritik dan saran yang diberikan.

\section{DAFTAR PUSTAKA}

1. Sjahmien Moehji. Pemeliharaan Gizi Orang Dewasa, Tenaga Kerja, dan Olahragawan. In: Ilmu Gizi 2, Penanggulangan Gizi Buruk. Jakarta: Papas Sinar Sinanti; 2009.p.68-108.

2. Undang-Undang Republik Indonesia No.13 Tahun 2003 tentang Ketenagakerjaan. [serial online] [cited 2013 Mei 02]. Available from: URL: http://prokum.esdm.go.id/uu/2003/uu-13-2003.pdf

3. Hilary J Forrester. Wise Up on Water, Water in The Workplace. Independent Researcher and Senior Policy Executive, Water Uk. [serial online] 2006 [cited 201322 April] Available from: URL: http://www.water.org.uk/home

4. Sumamur. Higiene Perusahaan dan Kesehatan Kerja (Hiperkes). Jakarta: Sagung Seto; 2009.p.1216.

5. Tarwaka, Solichul, Bakri, Lilik S. Ergonomi Untuk Keselamatan, Kesehatan Kerja, dan Produktivitas. Surakarta: Uniba Press; 2004.p.3143.

6. Hardinsyah, Dodik Briawan, et al. Studi Kebiasaan Minum dan Status Hidrasi pada Remaja dan Dewasa di Wilayah Ekologi yang Berbeda. Bogor: Perhimpunan Peminat Gizi dan Pangan Indonesia (Persagi), Departemen Gizi Masyarakat Fema IPB Bogor, Danone Aqua Indonesia; 2009.

7. Lawrence E. Armstrong. Assessing Hydration Status: The Elusive Gold Standard. Journal Of The American College of Nutrition. 2007; 26(5): 575s584 s.

8. Clap AJ, Bishop PA, Smith JF, Lloyd LK, Wright KE. A Review of Fluid Replacement for Workers in Hot Jobs. AIHA Journal. 2002; 63: 190-198.

9. Budi Iman S, Hardinsyah, Parlindungan Siregar, Sudung O. Pardede. Air Bagi Kesehatan. Jakarata: Centra Communications; 2011.

10. Robert W. Kenefick, Michael N. Sawka. Review: Hydration at The Work Site. Journal of The American College of Nutrition. 2007; 26(5): 597s$603 \mathrm{~s}$

11. Veronica S. Miller, Graham P. Bates. Hydration, Hydration, Hydration. Ann Occup Hyg. 2010; 54(2): 134-136.

12. SM Shirreffs. Markers of Hydration Status. European Journal of Clinical Nutrition. 2003; 57 Suppl 2: S6-S9.

13. DJ Brake, GP Bates. Fluid Losses and Hydration Status of Industrial Workers under Thermal Stress Working Extended Shifts. Occup Environ Med. 2003; 60: 90-96.

14. V Miller, G Bates. Hydration of Outdoor Workers in North-West Australia. J Occup Health Safety. 2007; 23(1): 79-87. 
15. Daru Lestantyo. Efek Pemberian Larutan Elektrolit pada Berat Jenis dan Osmolalitas Urin Dua Kelompok Pekerja dengan Paparan Panas (Tesis). Magister Gizi Masyarakat Program Pasca Sarjana Universitas Diponegoro; 2006.

16. Robert Carter, Samuel Nc, Carrie Rv, Michael Ns. Hypohydration and Prior Heat Stress Exacerbates Decreases in Cerebral Blood Flow Velocity during Standing. J Appl Physiol. 2006; 101: 1744-1750.

17. Graham P Bates, John Schneider. Hydration Status and Physiological Workload of UAE Construction Workers: A Prospective Longitudinal Observational Study. Journal of Occupational Medicine and Toxicology. 2008; 3(21): 1-10.

18. Graham Bates, Richard Parker, Liz Ashby, Tim Bentley. Fluid Intake and Hydration Status of Forest Worker: A Preliminary Investigation. International Journal of Forest Engineering. 2001; 12(2): 27-32.

19. Menteri Tenaga Kerja Republik Indonesia. Keputusan Menteri Tenaga Kerja Nomor: Kep51/Men/I999 tentang Nilai Ambang Batas Faktor Fisika di Tempat Kerja. Jakarta: 1999.

20. Badan Standardisasi Nasional. Standar Nasional Indonesia. Nilai Ambang Batas Iklim Kerja (Panas), Kebisingan, Getaran Tangan-Lengan dan Radiasi Sinar Ultra Ungu di Tempat Kerja. SNI 16-7063-2004.

21. Bruce Baker, John Ladue. How Heat Stress Affects Performance. [serial online] 2010 [cited 2013 April 22]. Available From: URL: http://ehstoday.com/health/news/heat-stressaffects-performance-7791

22. Ahrens Cd. Meteorology Today: An Introduction to Weather, Climate, and The Environment, 8th Ed. Canada: Thomson Brooks/Cole. 2007

23. Gustam. Faktor Risiko Dehidrasi pada Remaja dan Dewasa (Skripsi). Departemen Gizi Masyarakat Fakultas Ekologi Manusia IPB; 2012. 